\title{
Consumo de volumosos, produção e composição físico-química do leite de cabras F1 Boer $\times$ Saanen ${ }^{1}$
}

\author{
Elisa Köhler Osmari ${ }^{2}$, Ulysses Cecato ${ }^{3}$, Francisco de Assis Fonseca de Macedo ${ }^{3}$, Cláudio \\ Fabrício da Cruz Roma ${ }^{2}$, Juliana Cantos Faveri', Ilan Munhoz Ayer ${ }^{4}$
}

\author{
1 Trabalho financiado pela bolsa da CAPES. \\ 2 Programa de Pós-Graduação em Zootecnia da Universidade Estadual de Maringá-UEM. \\ ${ }^{3}$ Departamento de Zootecnia da UEM. \\ ${ }^{4}$ Curso de Graduação em Zootecnia da UEM.
}

RESUMO - Avaliaram-se os efeitos do fornecimento de volumosos suplementares sobre o consumo, a produção e a composição físico-química do leite de cabras F1 (Boer $\times$ Saanen). Utilizaram-se 18 cabras distribuídas em três baias, recebendo como suplemento, à vontade, silagem de sorgo, silagem de milho ou feno de amoreira com controle diário do consumo de matéria seca. A média diária para produção semanal foi calculada reunindo-se dados leiteiros em três períodos pós-parto: 1 (34 a 40 dias/7 dias); 2 [(64 a 70 dias/7 dias) + (91 a 97 dias)/7 dias)]/2; e 3 (125 a 131 dias/7 dias) e a média pontual diária do período pelas datas de referência dos períodos da média diária para produção semanal, que foi correlacionada à composição de gordura, proteína, lactose e extrato seco total e à contagem de células somáticas. Os dados semanais de acidez e densidade

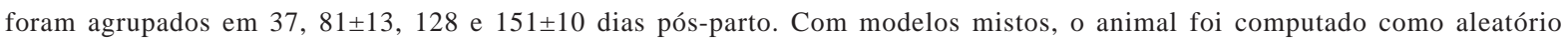
e os efeitos fixos foram três suplementos e três períodos (composição, médias diárias as produções semanal e do período) ou quatro (acidez e densidade). O consumo de feno de amoreira $(0,657 \mathrm{~kg})$ superou o de silagem de milho $(0,604 \mathrm{~kg})$, que foi superior ao de silagem de sorgo $(0,305 \mathrm{~kg})$. No período 2, a composição em extrato etéreo foi menor, em razão do decréscimo de gordura e lactose. No período 3, a composição em proteína e a acidez aumentaram e a densidade foi maior nos períodos $1(1,0270)$ e $3(1,0277)$. A mamite aumentou a CCS no período 2. Para proteína, o tipo de suplemento não foi significativo, mas houve efeito da interação período pós-parto $\times$ suplemento. As demais variáveis não foram influenciadas pelo tipo de suplemento, apenas pelo período pós-parto. O feno de amoreira aumenta o consumo suplementar pelas cabras em relação às silagens de milho e sorgo, mas não melhora as médias de produção e composição do leite. Cabras Boer $\times$ Saanen em pastejo e sob suplementação têm bom potencial leiteiro.

Palavras-chave: amoreira, caprinos, composição, forragem, leite, suplemento

\section{Roughage intake, milk yield and physicochemical composition from F1 Boer $\times$ Saanen goats}

\begin{abstract}
The effects were assessed of supplying supplementary roughage on intake, milk yield and milk physical and chemical composition in F1 (Boer $\times$ Saanen) goats. Eighteen females were placed in three stalls, and received as ad libitum supplement sorghum silage, corn silage and mulberry hay (MHT), with daily control of dry matter intake. The average daily production per week was calculated by gathering the milk data in three post-parturition periods: 1 (34-40 days/7 days); 2 $[(64-70$ days/7 days $)+(91-97$ days)/7 days)]/2 and 3 (125-131 days/7 days). Daily spot-average of each period (DSAP) was calculated from the reference dates of average daily production per week, that was correlated with the composition of fat, protein, lactose, total solids composition and the somatic cell count. The weekly data for acidity and density were grouped in 37, $81 \pm 13,128$ and $151 \pm 10$ days post-parturition. Using mixed models, the animal was computed as random and the fixed effects were three supplements and three periods (composition, average daily production per week and per period) or four (acidity and density). Mulberry hay intake $(0.657 \mathrm{~kg})$ was greater than corn silage $(0.604 \mathrm{~kg})$ that was greater than sorghum silage $(0.305 \mathrm{~kg})$. In period 2, the ether extract composition was smaller because of the decrease in fat and lactose. In period 3, protein and acidity increased and density was great in periods 1 (1.0270) and 3 (1.0277). Mastitis increased SCC in period 2. The type of supplement was not significant for protein, but there was post partum period $\times$ supplement effect. The other variables were not influenced by the type of supplement, only by the post-partum period. Mulberry hay increased the supplement intake by the goats compared to corn and sorghum silage, but it did not improve milk yield $=$ means and composition. Grazing Boer $\times$ Saanen goats with supplementation have good milk production potential.
\end{abstract}

Key Words: composition, goat, milk, mulberry, roughage, supplement 


\section{Introdução}

Por suas propriedades hipoalergênicas e alta digestibilidade, o leite de cabra é consumido principalmente por idosos, alérgicos e crianças (Haenlein, 2004). A produção comercial de leite caprino no Brasil iniciou-se na década de 70, nas regiões Sudeste e Sul. Hoje, já existem em várias regiões brasileiras produtos lácteos caprinos inspecionados, como leite em pó ultrapausterizado (UHT), iogurtes, doces e queijos (Resende \& Tosetto, 2004), e o primeiro chocolate ao leite de cabra em barra (Caprinforma, 2005). A especialização em laticínios de leite de cabra exige também maior qualidade da matéria-prima, tanto higiênica como de composição, volume, sazonalidade, nível tecnológico e saúde do rebanho (Resende \& Tosetto, 2004). Existe alta correlação entre o rendimento de queijos duros com a gordura, a proteína e o extrato seco total do leite de cabra (Fekadu et al., 2005). No sistema de duplo propósito carne/leite, utilizam-se fêmeas Boer $\times$ Saanen para leite e machos para corte, em razão dos altos preços pagos pela carne. Contudo, não existem pesquisas sobre a influência da dieta na composição e produção do leite de mestiças Boer. Além da raça, a produção de leite dos caprinos é afetada pela sazonalidade da pastagem. Mesmo o capimtifton 85, notável forrageira para caprino, em decorrência do porte baixo, da boa qualidade e da produtividade, não atende à exigência total de lactação no período da seca por causa do baixo teor energético da planta. As condições climáticas da Região Sul no inverno favorecem a utilização de gramíneas C3, como a aveia-preta, com alta proteína bruta, resistência ao frio, boa aceitabilidade e baixos teores de fibra (Moreira et al., 2001).

Entre as silagens, a de milho é a que possui mais energia por unidade de área, maior qualidade e melhor fermentação (Mizubuti et al., 2002). O uso de silagem de sorgo cresce no Brasil por causa da resistência dessa cultura ao estresse hídrico (Souza et al., 2003). A amoreira (Morus alba), além de muito palatável, possui altas concentrações de proteína e minerais, além de menos celulose e melhor digestibilidade das folhas em comparação às folhas de alfafa e de soja (Dorigan et al., 2004). Objetivou-se com este trabalho avaliar o consumo suplementar de volumosos conservados, a produção e a composição do leite de cabras primíparas F1 (Boer $\times$ Saanen) durante a lactação, sob sistema semiintensivo de pastejo.

\section{Material e Métodos}

O estudo foi conduzido no período de julho de 2004 a janeiro de 2005 na Fazenda Experimental de Iguatemi (FEI), nos Setores de Caprinocultura, Forragicultura e no Laboratório de Análise de Alimentos e Nutrição Animal (LANA) da Universidade Estadual de Maringá (UEM), em Maringá, Paraná. O clima local é classificado como $C f a$, subtropical úmido, mesotérmico com verões quentes e poucas geadas (Corrêa, 1996).

As 18 cabras primíparas lactantes, com peso vivo inicial de 46,87 kg em regime de semiconfinamento, foram alojadas em três baias coletivas de seis animais e receberam como suplemento silagem de sorgo, silagem de milho ou feno de amoreira, administrados à vontade com medição diária do consumo por baia. O manejo sanitário das cabras consistiu de vermifugações com evermectina, conforme resultados da contagem de ovos por grama de fezes (OPG>500) e controle da mamite com cloxacilina.

As áreas experimentais foram dois piquetes: um de aveia-preta (Avena strigosa Screbe, var. Iapar 61), com área de $7.927 \mathrm{~m}^{2}$ e um de capim-tifton 85 (Cynodon spp. cv. capim-tifton 85) com área de $6.995 \mathrm{~m}^{2}$, totalizando 1,49 ha de pastagens. A pastagem de aveia-preta foi implantada com aração e gradagem, com adubação de $220 \mathrm{~kg} / \mathrm{ha}$ de NPK 8-20-20 no plantio e mais 80,7 kg N/ha após 32 dias. Aplicou-se ureia em cobertura de $48 \mathrm{~kg}$ N/ha para a manutenção do piquete de capim-tifton. Cada cabra recebeu pela manhã, após a ordenha, 0,42 kg de matéria seca (MS) de concentrado com 13\% de proteína bruta (PB) e 73\% de NDT durante os primeiros 60 dias após a primeira parição. No período seguinte, foi fornecido concentrado com $17 \%$ de PB e 79\% de NDT, em razão da seca, que prejudicou a pastagem (Tabela 1).

Diariamente, após a primeira ordenha, todos os animais foram submetidos ao pastejo no período das $8 \mathrm{~h} 30$ às $11 \mathrm{~h}$ em piquete de aveia-preta. Por volta das $13 \mathrm{~h} 30$ às $16 \mathrm{~h}$, os animais eram conduzidos para o pastejo sobre o piquete de capim-tifton e em seguida recolhidos ao capril para a segunda ordenha e o fornecimento do volumoso suplementar nas baias, ao final da tarde.

A quantidade de volumoso fornecida foi calculada diariamente, de modo a ocorrer entre 10 e $20 \%$ de sobras, que eram pesadas e amostradas diariamente na manhã

Tabela 1 - Composição em ingredientes dos suplementos concentrados experimentais

\begin{tabular}{lcc}
\hline Ingrediente & \multicolumn{2}{c}{ Concentrado (\% MS) } \\
\cline { 2 - 3 } & 13 PB\% & 17 PB\% \\
\hline Milho & 76,88 & 71,38 \\
Farelo de soja & 13,50 & 22,96 \\
Farelo de trigo & 3,45 & - \\
Calcário & 3,09 & 2,99 \\
Núcleo mineral & 3,06 & 2,63 \\
Sal & 0,03 & 0,04 \\
\hline
\end{tabular}


seguinte. A lotação em pastejo foi fixada em 18 animais, e amostras da pastagem consumida foram coletadas por simulação de pastejo, também denominada hand-plucking (Sollenberger \& Cherney, 1995). A composição bromatológica dos alimentos (Tabela 2) foi analisada conforme descrito por Silva \& Queiroz (2002) para determinação dos teores de matéria seca total (MST), fibra em detergente neutro (FDN), fibra em detergente ácido (FDA), proteína bruta (PB) e extrato etéreo (EE), além da digestibilidade in vitro (DIVMS), determinada com fermentador ruminal Ankom ${ }^{\circledR}$.

Após as primeiras parições, foi iniciada a adaptação ao volumoso testado e, nas duas semanas precedentes à computação dos dados de consumo, procedeu-se à mudança do fornecimento do concentrado. Os dados de consumo foram avaliados a partir da média geral de 19 dias pós-parto e analisados por regressão polinomial de acordo com o tempo experimental em dias $(n=165)$. As equações obtidas para cada suplemento foram comparadas por análise de identidade de modelos (Graybill, 1976) e o consumo individual do suplemento, estimado de acordo com o consumo do lote, dividido pelo número de animais de cada lote.

Os dados para produção média de leite (kg/animal.dia) foram coletados de duas ordenhas diárias, usando-se duas metodologias:

MDPS - média diária para produção semanal, constituída pelos dados diários de produção de leite (kg/dia), agrupados nos seguintes períodos (PER): período 1 ( $\Sigma 34$ a 40 dias pósparto/7 dias), período 2 [( $\Sigma 64$ a 70 dias pós-parto/7 dias) + ( $\Sigma 91$ a 97 dias pós-parto)/7 dias)/2], período 3: ( $\Sigma 125$ a 131 dias pós-parto/7 dias); e MPDP - média pontual diária do período, constituída pelo período 1 (produção do 370 dia pós-parto), período 2 (produções do 67ํㅡ e 94ํㅡㅁ dias pósparto/2 dias) e período 3 (produção do 128 으 dia pós-parto).

Assim, estimou-se a melhor variável para produção de leite com medidas semanais ou mensais, por período de lactação. As cabras pariram em duas épocas (final de julho de 2004 e intervalo médio posterior de 19 dias, em agosto).
Cada suplementação alimentar foi equilibrada com cinco animais paridos no período 1 e um animal parido no período 2. Portanto, as 15 cabras paridas no período 1 tiveram seus períodos agrupados em: período 1 (agosto), período 2 (setembro + outubro) e período 3 (novembro), enquanto as três cabras paridas na segunda época foram agrupadas em período 1 (setembro), período 2 (outubro + novembro) e período 3 (dezembro). A composição mensal do leite foi avaliada a partir da média de 28 dias pós-parto das duas épocas de parição. Coletaram-se amostras (9h30 e 15h30) individuais de leite para formar uma amostra composta por 2/3 do leite da ordenha da manhã e 1/3 da produção da ordenha da tarde para manter a proporção produzida. Aproximadamente $50 \mathrm{~mL}$ foram acondicionados em frascos plásticos contendo conservante Bronopol (2-bromo-2-nitro-1,3-propanodiol) e remetidos ao Laboratório do Programa de Análises do Rebanho Leiteiro do Paraná (PARLPR), da Associação Paranaense de Criadores de Bovinos da Raça Holandesa, onde foram avaliados os teores de gordura, proteína bruta, lactose e extrato seco total, por meio de analisador infravermelho Bentley ${ }^{\circledR} 2000$, enquanto a contagem de células somáticas (CCS) foi feita com contador eletrônico Somacount $500^{\circledR}$. O monitoramento físico-químico semanal do leite foi feito por meio de análises de acidez e densidade, com solução Dornic de $0,1 \mathrm{~N}$ para titulação da acidez em $10 \mathrm{~mL}$ de leite.

A densidade, medida utilizando-se termolactodensímetro, em frascos com $250 \mathrm{~mL}$, foi corrigida para temperatura padrão de $15^{\circ} \mathrm{C}$ (Chornobai, 1998). Procedeu-se à secagem gradual das cabras com base no critério de produção média de três dias consecutivos inferior a $1 \mathrm{~kg}$ de leite/dia, com a secagem do primeiro animal iniciada aos 136 dias pós-parto. Para análise de acidez e densidade do leite, consideraram-se apenas as datas correspondentes à média da produção diária do período mais um último período, o 4; optou-se por tirar leite mesmo dos animais em processo de secagem, em virtude da fácil execução dessas análises no próprio capril. Os períodos para avaliação da acidez e densidade foram: período 1 (37 dias pós-

Tabela 2 - Composição dos concentrados, das pastagens e das forragens conservadas

\begin{tabular}{|c|c|c|c|c|c|c|c|}
\hline \multirow[b]{2}{*}{ Ingrediente $^{1}$} & \multicolumn{2}{|c|}{ Suplemento concentrado (\% MS) } & \multicolumn{2}{|c|}{ Pastagem $^{2}$ (\% MS) } & \multicolumn{3}{|c|}{ Forragem conservada (\% MS) } \\
\hline & $13 \mathrm{~PB} \%$ & $17 \mathrm{~PB} \%$ & Capim-tifton 85 & Aveia & $\begin{array}{c}\text { Silagem de } \\
\text { sorgo }\end{array}$ & $\begin{array}{l}\text { Silagem de } \\
\text { milho }\end{array}$ & $\begin{array}{c}\text { Feno de } \\
\text { amoreira }\end{array}$ \\
\hline Matéria seca & 83,62 & 84,60 & 33,27 & 21,40 & 30,32 & 30,86 & 82,19 \\
\hline Proteína bruta & 12,94 & 17,14 & 12,61 & 29,08 & 6,81 & 7,29 & 20,10 \\
\hline Extrato etéreo & $\mathrm{ND}^{3}$ & 2,51 & 1,79 & 3,38 & 1,27 & 1,97 & 0,93 \\
\hline Fibra em detergente neutro & 24,94 & 25,47 & 68,74 & 39,88 & 79,25 & 61,50 & 48,18 \\
\hline Fibra em detergente ácido & 4,48 & 4,98 & 32,81 & 19,31 & 44,60 & 32,48 & 35,40 \\
\hline Hemicelulose & 20,46 & 20,48 & 35,92 & 20,57 & 34,64 & 29,02 & 12,78 \\
\hline DIVMS & 91,55 & 89,34 & 61,78 & 88,98 & 56,81 & 71,17 & 72,85 \\
\hline
\end{tabular}

DIVMS = digestibilidade da matéria seca (DIVMS); 2 = amostras de simulação de pastejo; 3 = não-determinado. 
parto), período 2 ( $81 \pm 13$ dias pós-parto), período 3 (128 dias pós-parto) e período 4 (151 \pm 10 dias pós-parto).

Removeu-se o erro atribuído à variabilidade do animal, por meio da análise de modelos mistos, computado como efeito aleatório do volumoso. Utilizou-se arranjo fatorial $3 \times 3$, considerando os três períodos de dados para média diária para produção semanal (MDPS) e para média pontual diária do período (MPDP) agrupados, além de três suplementos (silagem de sorgo, silagem de milho e feno de amoreira), como efeitos fixos do modelo, aplicando-se os testes $\mathrm{F}$ e de Tukey. Em seguida, escolheu-se a metodologia mais adequada para medição da produção de leite, como efeito fixo, para análise da composição em gordura, proteína bruta, lactose e extrato seco total, da CCS e da acidez e densidade utilizando-se o arranjo fatorial $4 \times 3$ para acidez e densidade, em virtude dos quatro períodos.

\section{Resultados e Discussão}

O consumo de matéria seca apresentou diferenças $(\mathrm{P}<0,05)$ entre os volumosos testados, com regressão linear para a suplementação com silagem de milho e cúbica para as suplementações com silagem de sorgo e com feno de amoreira (Figura 1). O consumo observado nos animais alimentados com feno de amoreira teve o melhor ajuste, determinado pelo coeficiente de determinação $\left(\mathrm{R}^{2}=68,49 \%\right)$, com consumo médio de $0,657 \mathrm{~kg}$ MS/animal.dia, superior ao da silagem de milho $(0,604 \mathrm{~kg}$ MS/animal.dia), que foi superior ao da silagem de sorgo (0,305 kg MS/animal.dia). Outros autores têm observado aumento de $40 \%$ do consumo de MS por caprinos jovens recebendo suplemento de $0,75 \mathrm{~kg} / \mathrm{animal}$.dia (de 3,41\% do peso vivo) de silagem de amoreira em comparação ao consumo exclusivo de pastagens nativas (Ba et al., 2005).

O modelo ajustado para feno de amoreira, no entanto, estimou o consumo inicial com valores negativos (Figura 1), interpretado como baixo consumo de MS, seguido de aumento expressivo, até atingir o pico por volta da nona semana (58o dia experimental), quando ocorreu diminuição, seguida de tendência de estabilização ao final do período. $\mathrm{O}$ feno de amoreira continha alto teor de PB (20,10\%) e concentração relativamente baixa de FDN (48,18\%) e apresentou melhor DIVMS (72,85\%), que, em conjunto com a alta palatabilidade, aumentaram o consumo pelos animais.

Mesmo picado, o feno de amoreira permitiu maior seletividade pelos animais, que rejeitaram frações mais lignificadas do caule, pela sua alta densidade física em relação às folhas maceradas (Silva et al., 2005). De acordo com Zambom et al. (2005), o animal atinge consumo máximo de MS após o pico de lactação, o que explica em parte o comportamento cúbico de silagem de milho. A diminuição posterior do consumo de MS também refletiu a recuperação do equilíbrio metabólico no final da lactação, quando os animais requerem menos proteína e selecionam alimentos conforme seu equilíbrio nutricional, uma vez que a pastagem de capim-tifton continha teores mais baixos de proteína e maiores de fibras em comparação ao feno de amoreira (Tabela 2).

A maior ingestão inicial estimada da silagem de milho (0,332 kg MS animal/dia) em relação aos outros volumosos

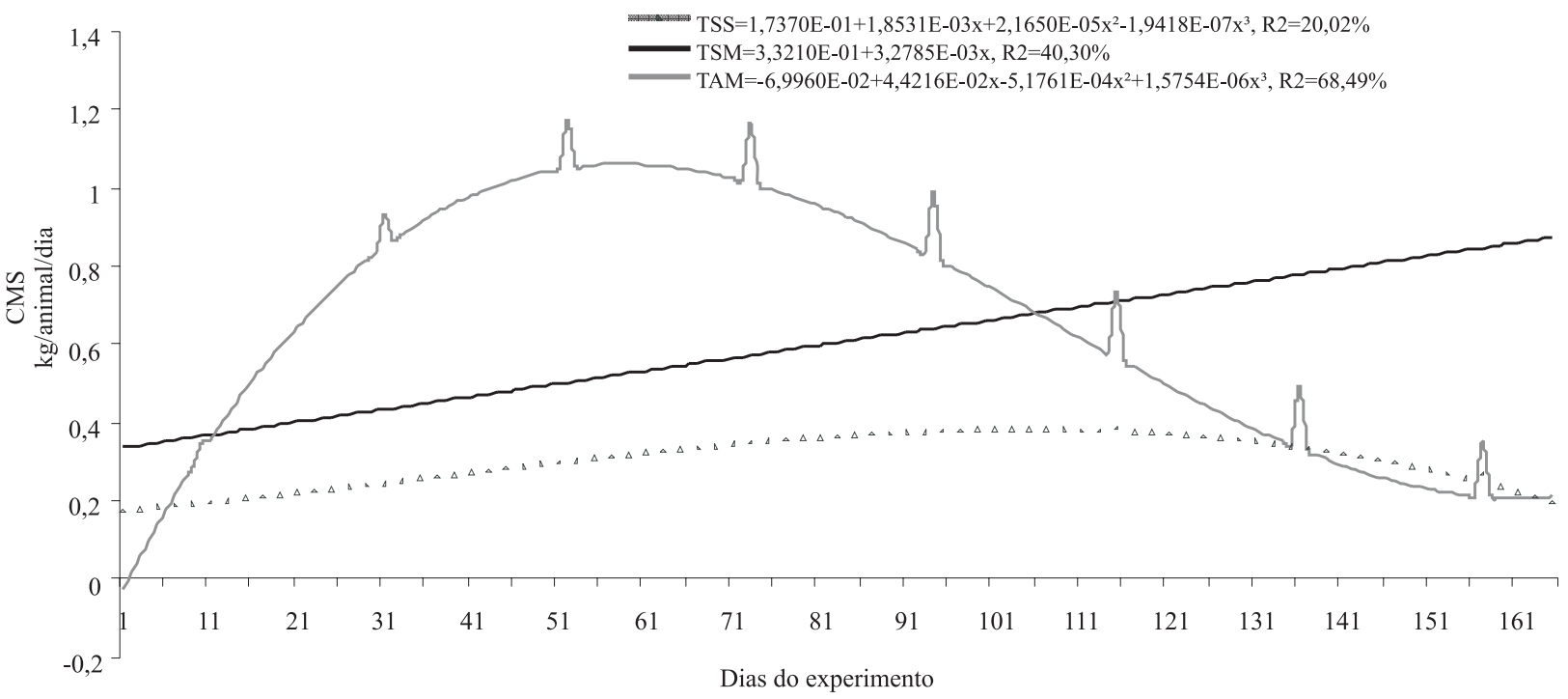

Figura 1 - Consumo suplementar de matéria seca por cabras lactantes em pastagens de aveia-preta e capim-tifton 85 sob suplementação com silagem de sorgo (TSS), silagem de milho (TSM) e feno de amoreira (TAM). 
suplementares foi atribuída ao hábito de consumo préexistente, tendo em vista a suplementação da dieta para os 18 animais durante o pré-parto, em período anterior à condução deste estudo. A silagem de milho foi retirada de dois silos porque foi utilizada em conjunto com outros setores, por isso seu teor de proteína bruta inicial de 6,08\% aumentou nas amostragens próximas ao final do trabalho (8,51\% PB), tornando-se inversamente proporcional à concentração de fibra em detergente neutro (FDN), de $63,69 \%$ do início para 59,48\% ao término, fatores qualitativos que aumentaram linearmente o consumo de silagem de milho pelos animais. Possivelmente, no início da lactação as pastagens de aveia e capim-tifton tiveram maior participação na dieta de silagem de milho, o que justifica a maior produção de leite inicial. A qualidade da silagem de sorgo foi inferior à dos demais volumosos, com teor de fibra em detergente neutro (FDN) bastante elevado (média $=79,25 \%$ ) e concentração de proteína bruta (PB) (6,81\%) relativamente baixa, proporcionando menor consumo médio desse suplemento em relação aos outros animais sob suplementação. As cabras que receberam silagem de sorgo compensaram o menor valor nutritivo consumindo mais pastagens (efeito substitutivo) nos períodos iniciais (aveia e tifton) e finais (capim-tifton). Não houve efeito significativo na produção de leite (Tabela 3) em relação aos demais suplementos. O maior consumo de silagem ocorreu nos períodos intermediários durante a estiagem e o final de ciclo da aveia (novembro). A alta lignificação, alta presença de fibra em detergente neutro e o alto tanino (Neumann et al., 2001) em algumas variedades de sorgo são fatores que reduzem o consumo de MS, a taxa e a extensão de degradação da matéria seca e da proteína bruta. A média diária da produção semanal e a média da produção do período decresceram ao longo dos períodos (Tabela 3) pelo teste de Tukey ( $\mathrm{P}<0,05)$, mas, na comparação da MPDP com a MDPS, verificou-se diminuição do coeficiente de variação e do erro experimental em favor de MDPS, demonstrando que fatores ambientais, como a demora no manejo na sala de ordenha na data de coleta do leite mensal, geraram algum estresse nos animais, aumentando a variabilidade extrínseca ao tratamento. A produção de leite (MDPS) não foi significativa para suplemento $(\mathrm{P}>0,05)$, mas a tendência de interação período $\times$ suplemento $(\mathrm{P}=0,076)$ sugere mais estudos sobre o uso desses alimentos para cabras ao longo da lactação.

Não existem dados disponíveis na literatura sobre a produção e composição do leite por cabras alimentadas com amoreira, embora seja utilizada a milênios em países asiáticos. Assim, pode-se considerar este experimento pioneiro em relação ao cruzamento de raças e às estratégias alimentares estudadas.

A estiagem, ocorrida no início da primavera e superior a 50 dias, dizimou a aveia-preta, acentuando a queda na produção de leite das cabras ao longo da lactação, mesmo com a mudança da ração basal de 13 para 17\% de PB. Um decréscimo linear na produção ao longo da lactação também foi encontrado por Ferreira (1996), que, ao trabalhar com 28 cabras de diversos graus de sangue Saanen suplementadas com feno de alfafa em sistema semi-intensivo com estrelaafricana, alegou que a capacidade produtiva e as exigências dos animais diminuem até o final da lactação.

Os dados deste experimento foram intermediários aos de Greyling et al. (2004), que trabalharam com condições nutricionais diversas durante os primeiros 84 dias de lactação, descartando-se a primeira semana pós-parto. Esses autores encontraram média de 3,1 L/dia para cabras Boer puras, superior à de 1,4 L/dia das raças nativas, ambas confinadas com $2 \mathrm{~kg} /$ dia de ração peletizada com 14\%PB, mas, em regime extensivo de pastagem nativa da África do Sul, não encontraram diferença entre a produção das raças Boer $(0,8 \mathrm{~L} /$ dia $)$ e animais nativos $(0,7 \mathrm{~L} / \mathrm{dia})$. A média pontual diária do período (MPDP) e a média diária para produção semanal (MDPS) de 1,48 kg e 1,47 kg deste trabalho, e a MPDP e MDPS de animais suplementados com silagem de sorgo, de 1,43 kg e 1,44 kg, respectivamente, foram semelhantes aos valores obtidos por Barros et al. (2005) para cabras multíparas dos cruzamentos $1 / 2$ Alpina + 1/2 Moxotó (1,54 L/dia), 3/4 Alpina + 1/4 Moxotó (1,33 L/dia) e $1 / 2$ Anglo-nubiana + 1/4 Alpina +1/4 Moxotó (1,36 L/dia), alimentadas com silagem de sorgo ad libitum e $0,8 \mathrm{~kg} /$ animal/dia de concentrado. A média diária para produção semanal encontrada para os animais suplementados com feno de amoreira, de 1,64 kg/dia, já que este alimento

Tabela 3 - Produção de leite para média pontual diária do período (MPDP), obtida da data da ordenha, para média diária para produção semanal (MDPS), por período pós-parto para cabras F1 (Boer $\times$ Saanen) sob suplementação com volumosos conservados

\begin{tabular}{|c|c|c|c|c|}
\hline \multirow[t]{2}{*}{ Item } & \multicolumn{3}{|c|}{ Média por período pós-parto } & \multirow[t]{2}{*}{ Média e erro-padrão } \\
\hline & Período 1 & Período 2 & Período 3 & \\
\hline $\begin{array}{l}\text { Média diária da produção do período, kg/dia } \\
\mathrm{CV}, \%\end{array}$ & $1,84 \mathrm{~A}$ & $1,42 B$ & $1,19 \mathrm{C}$ & $\begin{array}{c}1,48 \pm 0,11 \\
16,30\end{array}$ \\
\hline $\begin{array}{l}\text { Média diária da produção semanal, kg/dia } \\
\mathrm{CV}, \%\end{array}$ & $1,83 \mathrm{~A}$ & $1,49 \mathrm{~B}$ & $1,16 \mathrm{C}$ & $\begin{array}{c}1,47 \pm 0,10 \\
15,05\end{array}$ \\
\hline
\end{tabular}

Médias seguidas de letras distintas nas linhas diferem $(\mathrm{P}<0,05)$ entre si pelo teste Tukey. 
proporcionou maior CMS, especialmente no início da lactação, foi mais próxima da média de 1,89 kg de leite/dia encontrada por Zambom et al. (2005) para cabras Saanen multíparas alimentadas com $80 \%$ de volumoso e $20 \%$ de concentrado ao longo de 152 dias de lactação.

A diferença nos dados deste estudo em relação aos trabalhos realizados com a raça Saanen está relacionada ao fato de as fêmeas usadas neste trabalho serem primíparas mestiças consumindo dietas de menor concentração energética, com potencial produtivo inferior ao das raças leiteiras puras. Independentemente da raça, o nível nutricional afeta significativamente a produção e o consumo está correlacionado positivamente a maiores produções leiteiras (Greyling et al., 2004).

Não houve diferenças entre os suplementos para a composição em gordura, lactose e extrato seco total nem para contagem de células somáticas, mas houve efeito do período de lactação sobre as variáveis estudadas (Tabela 4).

Um fator extrínseco aos suplementos e que provavelmente contribuiu para a diminuição dos teores de gordura e lactose e o aumento da contagem de células somáticas foi a ocorrência generalizada de mamite na metade do período experimental. A gordura e a lactose foram afetadas negativamente pelos períodos 2 e 3 da lactação, enquanto a contagem de células somáticas aumentou com a ocorrência de mamite no período 2. Os conteúdos de gordura na cabra e na vaca aumentam após o parto e diminuem durante a maior parte da lactação, decréscimo que está relacionado ao efeito de diluição, ocasionado pelo aumento do volume de leite até o pico de lactação, e à diminuição da mobilização da gordura, que reduz a disponibilidade de protoplasma para síntese de lipídios mamários (Chilliard \& Ferlay, 2004).

O coeficiente de variação no percentual de gordura (Tabela 4) foi superior (12,81\%) ao das demais frações de proteína bruta, lactose e extrato seco total no período, o que pode estar relacionado às variações de temperatura, ao estágio de lactação, à produção de leite, ao tipo de alimentação e aos fatores genéticos e individuais (Chornobai, 1998). Os dados de composição do leite das mestiças Boer deste trabalho (Tabelas 4 e 5) são semelhantes aos encontrados por Soryal et al. (2005), de 3,87\% (PB), $4,37 \%$ (gordura) e $13,45 \%$ (extrato seco total) no leite de cabras Nubianas, raça africana como a Boer. Iaschi et al. (2004), ao compararem cabras Boer a um grupo nativo da Austrália, verificaram 9,97 e 7,07\% (gordura), 5,14 e 4,35\% (PB), 4,99 e 5,37\% (lactose) no leite de cabras Boer na 4a e 6a semanas de lactação.

No Brasil, Carvalho et al. (2006) encontraram 3,26\% de gordura, $11,77 \%$ de extrato seco total e $3,4 \mathrm{~kg}$ de leite/dia para Alpinas consumindo dieta (55,85\% de FDN e 18,25\% de PB) com $69,14 \%$ de feno de capim-tifton 85 , enquanto Zambom et al. (2008), ao estudarem níveis de 0-41,32\% de casca de grão de soja na dieta total, 13,29-15,98\% de PB e 30,88-49,65\% de FDN, obtiveram 3,18-3,19\% de gordura, 2,83-2,91\% de PB, 4,18-4,25\% de lactose e 11,22-11,69\% de extrato seco total no leite de cabras Saanen produzindo entre 2,33 e 3,38 kg de leite/dia. Para as raças alpinas na Europa, foram encontrados 3,40 e 2,95\% de PB, 3,77 e 3,36\% de gordura, 4,36 e $4,02 \%$ de lactose, 12,26 e $11,06 \%$ de extrato seco total, respectivamente, em rebanhos das raças Saanen e Alpina em pastagens C3 nos alpes da Eslovênia (Zan et al., 2006). Portanto, os valores do presente trabalho são intermediários aos obtidos com as raças alpinas e africanas supracitadas, como era esperado por se tratarem de fêmeas mestiças.

Alta contagem de células somáticas, em razão da desregulagem da filtração funcional da glândula mamária atacada, está ligada às modificações bioquímicas na composição do leite, como o aumento da concentração de proteínas solúveis e de minerais, como cloretos e sódio, durante uma infecção mamária (Raynal-Ljutovac et al., 2005), enquanto o cálcio e fósforo e a caseína tendem a diminuir. Neste experimento, provavelmente

Tabela 4 - Produção e composição centesimal do leite de cabras F1 (Boer $\times$ Saanen) no período pós-parto

\begin{tabular}{|c|c|c|c|c|}
\hline \multirow[t]{2}{*}{ Item } & \multicolumn{3}{|c|}{ Média por período pós-parto } & \multirow[t]{2}{*}{ Média e erro-padrão } \\
\hline & Período 1 & Período 2 & Período 3 & \\
\hline $\begin{array}{l}\text { Média diária da produção semanal, kg/dia } \\
\mathrm{CV}, \%\end{array}$ & $1,83 \mathrm{~A}$ & $1,49 B$ & $1,16 \mathrm{C}$ & $\begin{array}{c}1,47 \pm 0,10 \\
15,05\end{array}$ \\
\hline $\begin{array}{l}\text { Gordura, \% } \\
\mathrm{CV}, \%\end{array}$ & $4,72 \mathrm{~A}$ & $4,20 B$ & $4,17 B$ & $\begin{array}{c}4,36 \pm 0,15 \\
12,81\end{array}$ \\
\hline $\begin{array}{l}\text { Lactose, \% } \\
\mathrm{CV}, \%\end{array}$ & $4,78 \mathrm{~A}$ & 4,43B & $4,31 \mathrm{C}$ & $\begin{array}{c}4,44 \pm 0,06 \\
2,84\end{array}$ \\
\hline $\begin{array}{l}\text { Extrato seco total, \% } \\
\mathrm{CV}, \%\end{array}$ & $13,35 \mathrm{~A}$ & $12,72 \mathrm{~B}$ & $12,92 \mathrm{AB}$ & $\begin{array}{c}12,99 \pm 0,22 \\
5,24\end{array}$ \\
\hline $\begin{array}{l}\text { CCS, } \times 1000 / \mathrm{mL} \\
\mathrm{CV}, \%\end{array}$ & 898B & $2009 A$ & $1407 \mathrm{AB}$ & $\begin{array}{c}1448 \pm 324 \\
68,24\end{array}$ \\
\hline
\end{tabular}

Médias seguidas de letras distintas nas linhas diferem $(\mathrm{P}<0,05)$ entre si pelo teste Tukey. 
ocorreu substituição parcial da caseína por proteínas solúveis, a julgar pela alta CCS (Tabela 4) dos animais em geral no P2 (2009 × 1000 células/mL), motivo pelo qual a CCS e PB não tiveram praticamente correlação (Tabela 6), mascarando a influência qualitativa da CCS sobre a PB. A análise de caseína poderia comprovar essa hipótese, pois os animais sob suplementação com silagem de milho foram mais afetados numericamente, no período 2, pelo aumento da CCS, não acusada na análise (Tabela 4), em razão da alta variabilidade (erro-padrão $= \pm 324 \times 1000$ células $/ \mathrm{mL}$ ).

Para proteína bruta do leite (PB), não ocorreu diferença no percentual médio nas suplementações, mas houve interação pelo teste $\mathrm{F}(\mathrm{P}<0,01)$, com comportamento diferenciado para cada suplemento ao longo dos períodos (Tabela 5), com maior teor de PB no período 3 para cabras sob suplementação com silagem de milho em relação àquelas sob suplementação com amoreira e silagem de sorgo pelo teste de Tukey $(\mathrm{P}<0,05)$.

Chornobai (1998) afirma que, com a degradação da glândula mamária ao final da lactação dos caprinos, as infiltrações de proteínas sanguíneas no leite aumentam naturalmente, aumentando a CCS, como observado neste trabalho, pois o início do tratamento da mamite diminuiu numericamente a CCS no período 3, mas, ainda assim, foi 157\% numericamente superior à CCS do período 1 .

Paape et al. (2007) alegam que fatores não-infecciosos como ordem de parição e estágio de lactação, produzem efeitos mínimos na CCS de bovinos e ovinos, mas têm grande impacto na contagem em caprinos, motivo pelo qual deveriam ser reconsiderados os limites legais dos EUA para CCS caprina, de um milhão de células/mL. A CCS do leite de cabra normalmente supera a do leite de vaca, em virtude de diferenças interespecíficas, contudo, o alto valor neste trabalho também foi um indicativo de mamite, comprovada pelo California Mastitis Test (CMT).

O extrato seco total apresentou comportamento inverso ao da CCS, já que o incremento proteico do leite no período final possibilitou compensação relativa da queda nos teores de gordura e lactose, resultando em $12,99 \%$ de extrato seco total (Tabelas 4 e 6 ), pouco abaixo do observado por Montingelli (2005), de 14,50\%, para o leite de cabra e próximo do teor de $12,50 \%$ citado para leite de vaca. O conteúdo de extrato seco total deste trabalho pode ter sofrido certa diminuição, em decorrência dos quadros de mamite nos animais das três suplementações, visualizados no aumento exagerado da CCS. Nas correlações entre os constituintes do leite (Tabela 6), verifica-se alta correlação $(r=0,88)$ entre gordura e extrato seco total, de modo que a gordura demonstra ser o componente que mais influencia o comportamento do extrato seco, seguida de PB $(0,54)$.

A gordura manteve correlação positiva com MDPS $(0,34)$, pois ocorreu pequeno decréscimo percentual de gordura no período 2 da lactação seguido de certa estabilização, já que a fração da gordura foi afetada pela CCS (-0,32), assim como a lactose (-0.31), e ambas sofreram diminuição percentual, coincidindo com o decréscimo da produção de leite ao longo dos períodos. Alta CCS pode causar perdas de até $15-20 \%$ na produção leiteira (Raynal-Ljutovac et al., 2005).

Corroborando com os resultados de Greyling et al. (2004), a PB teve baixa correlação com a MDPS, mas neste trabalho a correlação também foi negativa $(-0,16)$, pois a $P B$ aumentou no período 3, de menor produção de leite, e a proteína foi o único componente centesimal que não pode ser correlacionado com CCS $(0,04)$. A correlação densidade/gordura $(0,18)$ foi menor que a encontrada por Chornobai (1998) para cabras 3/4 a 15/16 Saanen $(0,30)$ e, de acordo com esse autor, esperava-se um valor negativo, uma vez que a densidade diminui com o aumento percentual da gordura.

Quanto mais denso o leite, maior o rendimento na fabricação de queijos, o que reflete bom teor dos demais componentes sólidos, se relacionados positivamente ao teor de cálcio (Chornobai, 1998). A maior correlação está de acordo com Castro (2005), que cita a lactose como componente mais denso do leite de vaca $(1,666)$, ficando abaixo somente dos minerais $(5,500)$, seguido da proteína $(1,346)$, água $(1,000)$ e gordura $(0,930)$. Como a CCS influenciou negativamente a maioria das frações do leite,

Tabela 5 - Proteína bruta do leite (N x 6,38) corrigida por período pós-parto para cabras F1 (Boer $\times$ Saanen)

\begin{tabular}{lcccccccc}
\hline Período pós-parto & \multicolumn{6}{c}{ Proteína no leite } \\
\cline { 2 - 8 } & Silagem de sorgo & $\mathrm{N}$ & Silagem de milho & $\mathrm{N}$ & Feno de amoreira & $\mathrm{N}$ & Média & $\mathrm{N}$ \\
\hline Período 1 & $3,04 \mathrm{ABa}$ & 5 & $2,98 \mathrm{Bc}$ & 6 & $3,28 \mathrm{Aa}$ & 6 & $3,10 \mathrm{~b}$ & 17 \\
Período 2 & $3,08 \mathrm{Aa}$ & 6 & $3,30 \mathrm{Ab}$ & 6 & $3,08 \mathrm{Aa}$ & 6 & $3,15 \mathrm{~b}$ & 18 \\
Período 3 & $3,27 \mathrm{Ba}$ & 6 & $3,64 \mathrm{Aa}$ & 6 & $3,28 \mathrm{Ba}$ & 6 & $3,40 \mathrm{a}$ & 18 \\
Média & 3,14 & 17 & 3,31 & 18 & 3,21 & 18 & 3,22 & - \\
CV, \% & & & & & & \\
Erro-padrão & & & & & & \\
\hline
\end{tabular}

Médias seguidas com letras maiúsculas distintas diferem entre colunas e letras minúsculas indicam diferenças $(\mathrm{P}<0,05)$ entre linhas pelo teste Tukey. 
consequentemente diminuiu a qualidade do leite e sua densidade, reduzindo a acidez (Tabela 6). Tronco (1997) enumera a fraude e a mamite como fatores que diminuem o percentual de sólidos no leite de vaca, refletindo em acidez e densidade menores. Chornobai (1998) afirma que a razão principal do emprego da acidez titulável visa detectar leite acidificado e que índices muito baixos (menores que $11^{\circ} \mathrm{D}$ ) indicam mastite, alteração microbiana prejudicial ao sabor ou ainda nutrição inadequada. A alta CCS detectada neste trabalho, associada à relativa baixa acidez (Tabela 7), são indicativos de problemas no úbere, como mamites.

A maior correlação para acidez está ligada à PB $(0,44)$, dado condizente ao encontrado $(0,36)$ por Chornobai $(1998)$, o qual afirma que a maior influência vem da caseína, principal fração proteica do leite de cabra e também a responsável, juntamente com sais minerais e íons, pela acidez natural.

A correlação entre acidez e PB (Tabelas 4 e 7) refletiu no comportamento da acidez e da proteína ao longo da lactação, que só diferiram a partir dos 128 dias, com tendência para período $\times$ suplemento $(\mathrm{P}<0,07)$ para acidez. $\mathrm{O}$ tratamento da mamite influenciou positivamente os conteúdos de acidez e densidade (Tabelas 6 e 7). Mesmo com decréscimo da lactose no período 3 , o aumento do teor proteico permitiu elevação da densidade, quadro que não permaneceu no período 4 .

De modo geral, todos os parâmetros encontrados atenderam às faixas preconizadas na legislação brasileira para o leite de cabra (MAPA, 2000), exceto a densidade, que ficou próxima do valor mínimo de $1,0280 \mathrm{~g} / \mathrm{cm}^{3}$, com média de $1,0272 \mathrm{~g} / \mathrm{cm}^{3}$; e a CCS, cujo valor médio de 1.448 x 1.000 ultrapassou o valor máximo permitido de um milhão de células somáticas por mL (Paape et al., 2007).

Assim, pode-se considerar bom potencial produtivo de leite para cabras (Boer $\times$ Saanen), mediante a utilização de diferentes volumosos como principal fonte de alimento.

Tabela 6 - Matriz de correlação de Pearson para produção de leite, composição centesimal e físico-química do leite de cabras F1 (Boer $\times$ Saanen)

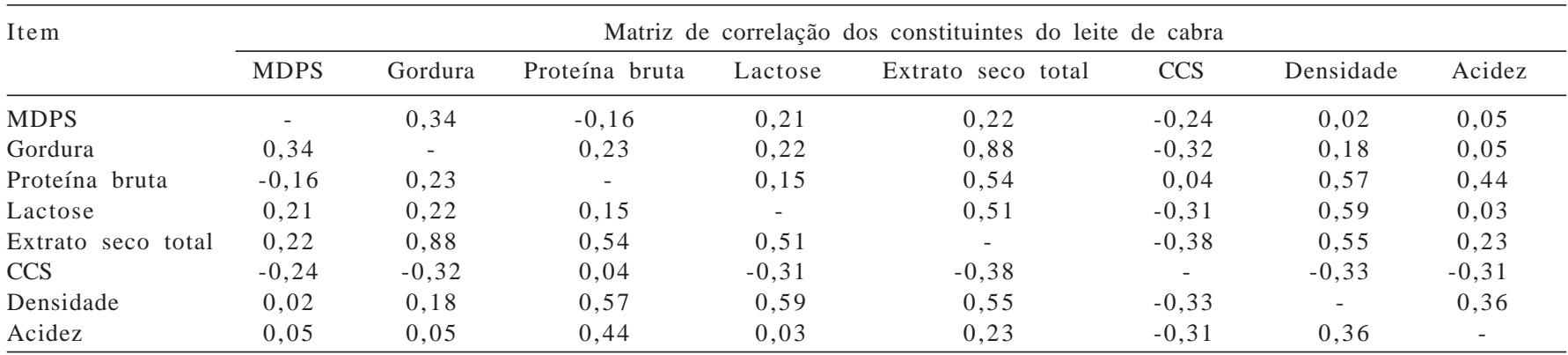

Média diária de produção semanal (MDPS) de leite; CCS - contagem de células somáticas.

Tabela 7 - Teores médios de acidez $\left({ }^{\circ} \mathrm{D}\right)$ e densidade do leite $\left(\mathrm{g} / \mathrm{cm}^{3}\right)$ à temperatura de $15^{\circ} \mathrm{C}$ corrigidas por período para fornecimentos de volumosos para cabras F1 (Boer $\times$ Saanen)

\begin{tabular}{|c|c|c|c|c|c|c|c|c|c|}
\hline \multirow[t]{2}{*}{ Item } & \multicolumn{8}{|c|}{ Período de dias pós-parto } & \multirow[t]{2}{*}{ Média e erro-padrãc } \\
\hline & Período 1 & $\mathrm{~N}$ & Período 2 & $\mathrm{~N}$ & Período 3 & $\mathrm{~N}$ & Período 4 & $\mathrm{~N}$ & \\
\hline \multirow{2}{*}{$\begin{array}{l}\text { Acidez, } \mathrm{D}^{\circ} \\
\mathrm{CV}, \% \\
\text { densidade, } \mathrm{g} / \mathrm{cm}^{3} \\
\mathrm{CV}, \%\end{array}$} & $13,81 \mathrm{C}$ & 18 & $14,32 \mathrm{BC}$ & 18 & $15,51 \mathrm{~A}$ & 18 & $15,12 \mathrm{AB}$ & 15 & $\begin{array}{c}14,57 \pm 0,51 \\
7,86\end{array}$ \\
\hline & $1,0270 \mathrm{AB}$ & 18 & $1,0267 \mathrm{BC}$ & 18 & $1,0277 \mathrm{~A}$ & 18 & $1,0257 \mathrm{C}$ & 15 & $\begin{array}{c}1,0272 \pm 0,0004 \\
4,22\end{array}$ \\
\hline
\end{tabular}

Médias seguidas de letras distintas nas linhas diferem entre si pelo teste Tukey $(\mathrm{P}<0,05)$.

\section{Conclusões}

O feno de amoreira,em relação às silagens de milho e sorgo, aumenta o consumo de suplemento pelas cabras, mas não melhora as médias de produção e composição do leite, ao passo que o período de lactação influencia a concentração dos constituintes lácteos. Cabras F1 (Boer $\times$ Saanen) em pastejo consumindo suplemento à base de volumosos têm bom potencial leiteiro.

\section{Literatura Citada}

ASSOCIAÇÃO DOS CAPRINOCULTORES DO RIO GRANDE DO SUL - CAPRISUL. Caprinocultores começam a se organizar em Santa Cruz. Informativo Caprinforma, ano 2, 6.ed. Porto Alegre: Associação dos Caprinocultores do Rio Grande do Sul, 2005. 4p

BA, N.X.; GIANG, V.D.; NGOAN, L.D. Ensiling of mulberry foliage (Morus alba) and the nutritive value of mulberry foliage silage for goats in central Vietnam. In: Livestock Research for Rural Development, v.17, n.2, p.1-9, 2005. Disponível em: <http:// www.cipav.org.co/lrrd/lrrd17/2/ba17015.htm>. Acesso em: 3/4/2005. 
BARROS, N.N.; SILVA, F.L.R.; ROGÉRIO, M.C.P. Efeito do genótipo sobre a produção e a composição do leite de cabras mestiças. Revista Brasileira de Zootecnia, v.34, n.4, p.1366-1370, 2005.

BRASIL [2000]. Ministério da Agricultura, Pecuária e Abastecimento. Regulamento técnico de produção, identidade e qualidade do leite de cabra. 2000. 8p. Disponível em: <http:www.agricultura.gov.br/sda/dipoa/ anexo_leitedecabra.htm>. Acesso em: 10/5/2001.

CARVALHO, S.; RODRIGUES, M.T.; BRANCO, R.H. et al. Consumo de nutrientes, produção e composição do leite de cabras da raça Alpina alimentadas com dietas contendo diferentes teores de fibra. Revista Brasileira de Zootecnia, v.35, n.3, p.1154-1161, 2006 (supl.).

CASTRO, P.S. MAF 3340-Tecnologia de leites e derivados. Apostila de aulas práticas. Goiânia: Departamento de Matemática e Física. Curso de Engenharia de Alimentos, Universidade Católica de Goiás, 2005. 25p. Disponível em: <http://www.ucg.br/ site_docente/maf/patricia/Apostila\%20de\%20Aula_Pratica.pdf >. Acesso em: 12/2/2006.

CHILLIARD, Y.; FERLAY, A. Dietary lipids and forages interactions on cow and goat milk fatty acid composition and sensory properties. Reproduction, Nutrition and Development, v.44, p.467-492, 2004.

CHORNOBAI, C.A.M. Avaliação físico-química de leite in natura de cabras cruza Saanen, ao longo do período de lactação. 1998. 100f. Dissertação (Mestrado em Química) Universidade Estadual de Maringá, 1998.

CORRÊA, A.R. Forrageiras: aptidão climática do Estado do Paraná. In: MONTEIRO, A.L.G.; MORAES, A.; CORRÊA, E.A.S. et al. (Eds.). Forragicultura no Paraná. Londrina: Comissão Paranaense de Avaliação de Forrageiras, 1996. p.15-22.

DORIGAN, C.J.; RESENDE, K.T.; BASAGLIA, R. et al. Digestibilidade in vivo dos nutrientes de cultivares de amoreira (Morus alba L.) em caprinos. Ciência Rural, v.34, n.2, p.539-544, 2004.

FEKADU, B; SORYAL, K.; ZENG, S. et al. Changes in goat milk composition during lactation and their effect on yield and quality of hard and semi-hard cheeses. Small Ruminant Research, v.59, p.55-63, 2005.

FERREIRA, A.C.D. Efeito da suplementação com concentrados no desempenho de cabras leiteiras a pasto. 1996. $17 \mathrm{f}$. Trabalho de Conclusão (Graduação em Zootecnia) - Universidade Estadual de Maringá, 1996.

GRAYBILL, F.A. Theory and application of the linear model. Massachusetts: Duxbury Press, 1976. 704p.

GREYLING, J.P.C.; MMBENGWA, V.M.; SCHWALBACH, L.M.J. et al. Comparative milk production potential of Indigenous and Boer goats under two feeding systems in South Africa. Small Ruminant Research, v.55, p.97-105, 2004.

IASCHI, S.P.A.; HUI, J.; CHONG, F.N. et al. Comparative of milk quality of the South African Boer and Australian Rangeland goats. Small Ruminant Research v.53, p.181-184, 2004.

HAENLEIN, G.F.W. Goat milk in human nutrition. Small Ruminant Research, v.51, p.155-163, 2004.

MIZUBUTI, I.Y.; RIBEIRO, E.L.A.; ROCHA, M.A. Consumo e digestibilidade aparente das silagens de milho (Zea mays $L$.), sorgo
(Sorghum bicolor (L.) Moench) e girassol (Helianthus annuus L.) Revista Brasileira de Zootecnia, v.31, n.1, p.267-272, 2002.

MONTINGELli, N.M.M. Pré-disposição do leite de cabra para a fabricação de queijos. 2005. 50f. Monografia (Pósgraduação Lato Sensu em Controle de Qualidade de Alimentos) - Universidade Federal de Lavras, 2005.

MOREIRA, F.B.; CECATO, U.; PRADO, I.N. et al. Avaliação de aveia preta $c v$ Iapar 61 submetida a níveis crescentes de nitrogênio em área proveniente de cultura de soja. Acta Scientiarum, v.23, n.4, p.815-821, 2001.

NEUMANN, M.; RESTLE, J.; ALVES FILHO, D.C. et al. Avaliação da silagem de diferentes híbridos de sorgo (Sorghum bicolor, 1. Moench) por meio do desempenho de novilhos de corte confinados. Revista Brasileira de Zootecnia, v.30, n.6, p.2099-2109, 2001

PAAPE, M.J.; WIGGANS, G.R.; BANNERMAN, D.D. Monitoring goat and sheep milk somatic cell counts. Small Ruminant Research, v.68, p.114-125, 2007.

RAYNAL-LJUTOVAC, K.; GABORIT, P.; LAURET, A. The relationship between quality criteria of goat milk, its technological properties and the quality of the final products. Small Ruminant Research, v.60, p.167-177, 2005.

RESENDE, K.T.; TOSETTO, E.M. Avaliação de estratégias de manejo em criatórios de caprinos leiteiros. In: ENCONTRO NACIONAL PARA O DESENVOLVIMENTO DA ESPÉCIE CAPRINA, 8., 2004, Botucatu. Anais... Botucatu: UNESP/ FMVZ, 2004. p.184-198.

SORYAL, K.; BEYENE, F. A.; ZENG, S. et al. Effect of goat breed and milk composition on yield, sensory quality, fatty acid concentration of soft cheese during lactation. Small Ruminant Research, v.58, p.275-281, 2005.

SILVA, D.J.; QUEIROZ, A.C. Análise de alimentos: métodos químicos e biológicos. 3.ed. Viçosa, MG: UFV, 2002. 235p.

SILVA, H.G.O.; PIRES, A.J.V.; SILVA, F.F. et al. Farelo de cacau (Theobroma cacao L.) e torta de dendê (Elaeis guineensis, Jacq) na alimentação de cabras em lactação: consumo e produção de leite. Revista Brasileira de Zootecnia, v.34, n.5, p.1786-1794, 2005.

SOLLENBERGER, L.E.; CHERNEY, D.J.R. Evaluating forage production and quality. In: The Science of grassland agriculture. Ames: Iowa State University Press, 1995. p.97-110.

SOUZA, V.G.; PEREIRA, O.G.; MORAES, S.A. et al. Valor nutritivo de silagens de sorgo. Revista Brasileira de Zootecnia, v.32, n.3, p.753-759, 2003.

TRONCO, V.M. Manual para inspeção da qualidade do leite. Santa Maria. Universidade Federal de Santa Maria, 1997. 166p.

ZAMBOM, M.A.; ALCALDE, C.R.; SILVA, K.T. et al. Ingestão, digestibilidade das rações e produção de leite em cabras Saanen submetidas a diferentes relações volumoso:concentrado na ração. Revista Brasileira de Zootecnia, v.34, n.6, p.2505-2514, 2005 (supl.).

ZAMBOM, M.A.; ALCALDE, C.R.; SILVA, K.T. et al. Desempenho e digestibilidade dos nutrientes de rações com casca do grão de soja em substituição ao milho para cabras Saanen em lactação e no pré-parto. Revista Brasileira de Zootecnia, v.37, n.7, p.1311-1318, 2008.

ZAN, M.; STIBILJ, V.; ROGELJ, I. Milk fatty acid composition of goats grazing on alpine pasture. Small Ruminant Research, v.64, p.45-52, 2006. 